\title{
Mortality and cancer incidence among secondary lead smelter workers
}

\author{
Lars Gerhardsson, Lars Hagmar, Lars Rylander, Staffan Skerfving
}

\begin{abstract}
Objectives-To examine the mortality pattern and the cancer incidence in a cohort of long term smelter workers exposed to lead.

Methods-The cohort consists of 664 male lead battery workers, employed for at least three months in 1942-87. From 1969 the values of all blood lead samples repeatedly obtained from these workers every two to three months, have been collected in a database. The expected mortality and morbidity 1969-89 was estimated from the county rates, specified for cause, sex, five-year age groups, and calendar year. Individual exposure matrices have been calculated and used for dose-response analyses.

Results-The total cohort showed an
\end{abstract} increased overall mortality (standardised mortality ratio (SMR) $1 \cdot 44$; $95 \%$ confidence interval $(95 \% \mathrm{CI}) 1 \cdot 16-1 \cdot 79)$, an increased mortality from ischaemic heart diseases (SMR 1.72; 95\% CI 1.20-2.42) and all malignant neoplasms (SMR 1.65; 95\% CI 1.09-2.44). These risk estimates were unaffected or slightly decreased when applying a latency period of 15 years, and no dose-response pattern was shown. The non-significantly raised cancer incidence in the gastrointestinal tract (11 malignancies) in the total cohort, increased to a barely significant level in the quartile with the highest cumulative lead exposure (standardised incidence ratio (SIR) $2 \cdot 34,95 \%$ CI $1 \cdot 07-4 \cdot 45$ ). No clear dose response pattern was evident when further subdividing the data into those first employed up to $1969 \mathrm{v}$ those first employed after 1969 when the blood lead monitoring programme started. The risk estimate for malignancies in the gastrointestinal tract was not related to latency time. The cancer incidence was not increased at other sites.

Conclusions-A slightly increased incidence of gastrointestinal cancers was found in workers exposed to lead and employed before 1970. The lead cohort also showed an increased mortality from ischaemic heart diseases. These risk estimates did not show a dose-response pattern and were not associated with latency time. The results must also be interpreted with caution because of limited numbers, and lack of dietary and smoking data.

(Occup Environ Med 1995;52:667-672)
Keywords: inorganic lead; gastrointestinal malignancies; ischaemic heart diseases; lead smelter workers

Several animal experiments have shown a tumorigenic effect of lead. Soluble lead salts such as lead acetate and lead subacetate have produced kidney and brain tumours, and lead phosphate kidney tumours in rodents after oral or parenteral administration. ${ }^{1-6}$ The development of malignancies mostly occurred in rats at very high exposures, for example about $10000 \mathrm{ppm}$ of soluble lead in food or drinking water. Thus, these effects seem to take place at doses that are close to the maximum tolerable dose and well above the dose that is acutely toxic to the target organ. ${ }^{7}$ Synergistic effects for the development of cancer between lead acetate and lead oxide and some organic carcinogens, such as benzo(a)pyrene and nitrosoamines have also been reported. ${ }^{5}$ Sufficient data are not available for a proper evaluation of metallic lead, lead oxide, and lead tetraalkyls.

A few case reports of kidney cancer in workers exposed to lead have been presented. ${ }^{89}$ In a study in Finland of work related kidney cancer (adenocarcinomas), there was a non-significantly increased risk related to lead exposure. ${ }^{10}$ In general, the epidemiological studies undertaken do not support a carcinogenic effect of inorganic lead in humans, although the exposure in several studies has been rather high (> $3.0 \mu \mathrm{mol} / 1$ blood). Small excess risks have been found in a few studies, but they could be attributed to confounding factors. In 1987, the International Agency for Research on Cancer (IARC) concluded that the evidence for carcinogenicity of lead in humans was insufficient. $^{5}$

The disagreement between epidemiological studies and animal experiments could be due to differences in exposures or to differences in species sensitivity. Doses given in experiments may be more than 1000 -fold higher than permissible exposure limits in different countries. Exposures of that magnitude would send a hypothetical lead worker to the hospital within days or weeks. ${ }^{7}$ Considerable differences exist between rats and hamsters or dogs. It is plausible that such differences also exist between rats and humans, which complicates extrapolation of results from animal experiments. Nevertheless, further studies are needed to clarify the concern about human carcinogenicity of lead.

The aim of the present study was to assess the mortality pattern and the cancer incidence among workers exposed to lead from a 
secondary smelter without any concomitant occupational exposure to lung carcinogens such as arsenic, cadmium, chromium, and nickel and with limited exposure to polycyclic aromatic hydrocarbons (PAHs).

\section{Materials and methods}

THE PLANT AND LEAD PRODUCTION

The secondary lead smelter in southern Sweden was started in 1942 . The production of inorganic lead has been between 37000 and 40000 tonnes a year during the 1990s. During the 1950 s the production was lower, about 10000 tonnes a year, and during the 1960s-1980s about 30000 tonnes a year. Also, the company has an annual tin production of about 2000 tonnes.

The raw materials for lead and lead alloys are obtained from different sources. Scrap lead from telephone cables and old car, bus, and lorry batteries forms the largest single group of raw materials. Other sources include lead ashes from rubber companies, iron works, and glassworks, where lead is used to impart a beautiful lustre to crystal. The raw materials are mixed in a large blast furnace, producing blocks of raw lead weighing about $2700 \mathrm{~kg}$.

These are transported to the refining section and converted into new, high grade metal and metal alloys in the form of ingots. The products consist primarily of various types of lead-antimony alloys for car batteries, cables, and ammunition, as well as pure unalloyed lead for the rubber industry, among others.

There have been between 150 and 160 workers during most of the follow up period (see later section). Due to new technology gradually enforced, this has now reduced to about 100 workers.

\section{LEAD EXPOSURE}

Since 1969, the values of all blood lead samples obtained from the workers have been collected in a database at the company. Due to the Swedish regulation, blood lead sampling has usually been performed every two to three months over the years. Thus, it has been possible to calculate a time integrated blood lead index for each lead worker in the cohort, according to the following equation, adopted from Hogstedt et al. ${ }^{11}$

TWA B-Pb $=$

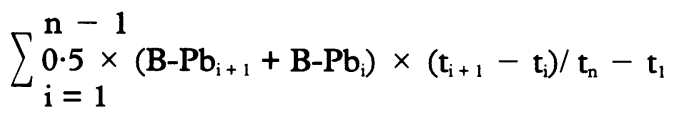

where $t_{i}$ is the time of measurement at time $i$, and $\mathrm{B}-\mathrm{Pb}_{\mathrm{i}}$ the blood lead concentration at time $\mathrm{i}$. Accordingly, $i+1$ is the measurement after $i$, and $t_{n}$ the time of the last measurement. Based on this index, the quartile of lead workers with the highest cumulative lead exposure was defined (75th percentile $300 \mu \mathrm{mol} / 1 \times$ months; lowest observed value in the cohort $0.4 \mu \mathrm{mol} / 1 \times$ months; highest observed value $1800 \mu \mathrm{mol} / 1 \times$ months). Besides the cumulative lead exposure intensity over time and peak blood lead concentrations that exceeded $3.4 \mu \mathrm{mol} / 1$ were used as exposure variables.

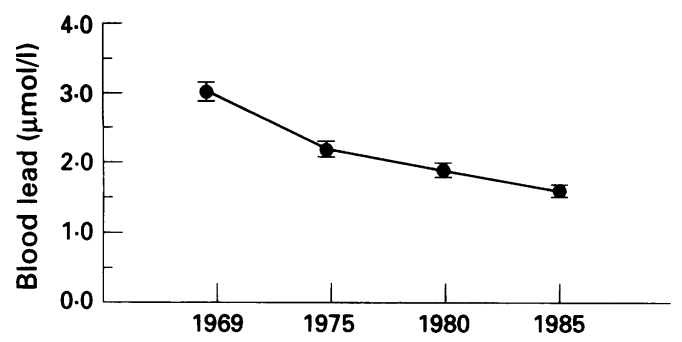

Figure Annual mean (arithmetic (95\% CI)) blood lead values in lead smelter workers from 1969-85.

The lead exposure among the smelter workers had gradually declined during the follow up period from a mean concentration of $3.0 \mu \mathrm{mol} \mathrm{Pb} / 1$ in 1969 to $1.6 \mu \mathrm{mol} / 1$ in 1985 (figure).

For lead workers employed before 1969 when the blood lead monitoring started, their previous lead exposure has been estimated from their exposure during 1969.

\section{BLOOD LEAD SAMPLING}

Venous blood obtained from the cubital vein has been collected in metal free heparinised evacuated tubes. Five $\mathrm{ml}$ samples have been wet ashed, and the lead then combined with dithizone, extracted, and measured by flame atomic absorption spectrophotometry (AAS). All analyses have been made in duplicate. The coefficient of variation calculated from duplicate determinations (precision) has usually been less than $5 \%$. The detection limit has been about $0.05 \mu \mathrm{mol} / 1(10 \mu \mathrm{g} / \mathrm{l})$.

Since 1971, the laboratory has participated in a Nordic calibration programme between laboratories and the accuracy has been tested twice every year. The results during the study period have agreed well with the expected concentrations. ${ }^{12}$ Since 1983 , the laboratory has participated in the United Kingdom external quality assessment scheme. The results have consistently been in good agreement with expected concentrations ( $95 \%$ of measurements $< \pm 5 \%$; $5 \%$ of measurements $5 \%$ $20 \%$ ). The quality control series have not displayed any time trends.

Before 1973 a colourimetric method was used for blood lead determinations, after extraction with dithizone in chloroform. The ashing procedure and the set up of blanks, standards, and samples was the same as for the flame AAS method. A separation step involving precipitation of lead with calcium phosphate from a solution containing oxalate of about pH 5 was used to eliminate colourimetric disturbances from iron in the chloroform dithizone extract.

Potassium cyanide was added to the ammonia citric acid buffer solution to avoid interferences from-for example, cadmium, copper, and zinc. The detection limit of this method was $0.05 \mu \mathrm{mol} / \mathrm{l}$. During a transition period of about one year both methods were used in parallel. The values obtained by the colourimetric method were somewhat higher (mean 
(SD) $105 \%(5 \cdot 8 \%) ; \mathrm{n}=24)$ in the concentration range $0.3-1.9 \mu \mathrm{mol} / 1$, although there was no difference $(100 \%(4 \cdot 8 \%) ; n=34)$ between the methods at blood lead concentrations $\geqslant 2 \cdot 0 \mu \mathrm{mol} / 1 .^{12}$

\section{COHORT}

In 1969, when the blood lead sampling programme started, 201 male smelter workers exposed to lead were employed at the plant, and had been so for at least three months. The 463 male workers who were employed for at least three months in 1970-89 were also included in the cohort. For 60 workers, date of both start and end of employment were unknown and they were therefore not included in the cohort. Moreover, 21 workers of Danish origin were also not included in the cohort, as they could not be tracked down in the Swedish population register. The final cohort therefore comprised 664 subjects, of which 24 had emigrated before 31 December 1989 when vital status was determined. In the cohort, the median calendar year of birth was 1943 (10th percentile 1918; 90th percentile 1960), the median first calendar year of exposure was 1973 (10th percentile 1952; 90th percentile 1985), the median duration of employment was 2.8 years (10th percentile 0.3 ; 90 th percentile 25.7 ) and the median duration of follow up was 13.8 years (10th percentile $2 \cdot 8$; 90th percentile $20 \cdot 9$ ).

\section{INFORMATION ON CAUSES OF DEATHS AND TUMOURS}

Information on causes of death 1969-89 was obtained from Statistics Sweden. The death certificates were coded according to the 8th revision of the international classification of diseases (ICD-8).

Information on at most two malignancies, coded according to ICD-7, and diagnosed from 1969 to 1989 , was obtained from the National Swedish Tumour Registry. One of the workers exposed to lead had two malignancies during the observation period (first: prostate tumour; second: small intestinal tumour).

For all 11 malignancies in the gastrointestinal tract, data from the histological and cyto- logical examination of the tumours have been scrutinised.

\section{RISK ESTIMATES}

Expected mortality for the period 1969-89 was calculated by calendar year, cause, sex, and five-year age group specific mortalities for the county population. These rates were obtained from Statistics Sweden. Date of death, emigration, or a persons 80th birthday, were used as individual endpoints, whichever occurred first. Similarly, yearly incidences for cancer in the period 1969-89 were obtained from the National Swedish Tumour Registry, with calendar year, sex, and five-year age group specific incidences for the county population. Date of death, tumour diagnosis, emigration, or a persons 80th birthday, were used as individual endpoints, whichever occurred first. The $95 \%$ confidence intervals (95\% CIs) for cause specific standardised mortality ratios (SMRs) and standardised cancer incidence ratios (SIRs) were calculated by treating the observed number as a Poisson variable or a normal variable if the observed value was greater than 15 .

\section{Results}

Compared with the county population, the cohort showed an increased total mortality (SMR 1.44; 95\% CI 1.16-1·79), an increased mortality from ischaemic heart diseases (SMR $1 \cdot 72$; $95 \%$ CI $1 \cdot 20-2 \cdot 42)$, accidents, poisoning, and violence (table 1 ). The mortality from malignant neoplasms was also raised (SMR 1.65; 95\% CI 1.09-2.44).

The increased risk of death in accidents, poisoning, and violence was only seen in the subcohort consisting of workers first employed in or after 1970. For other causes of death, year of employment only marginally affected the risk estimates. A latency period of 10 years did not substantially affect any of these risk estimates, but a latency period of 15 years decreased them somewhat (data not shown).

Those employed in or after 1970 contributed very few person-years to the highest quartile of lead exposure ( $>300 \mu \mathrm{mol} / 1 \times$ months). The mortality risks for the quartile of

Table 1 Mortality (observed/expected number of deaths) in the total cohort of 664 workers exposed to lead (8706 personyears) in comparison with the county population, during the follow up period 1969-89. (The calculations were based on 201 subjects contributing 3648 person-years in those first employed up to 1969, and 463 subjects contributing 5058 personyears in those first employed after 1969.)

\begin{tabular}{|c|c|c|c|c|c|c|c|c|c|}
\hline \multirow[b]{3}{*}{ Cause of death ICD-8 } & \multirow{3}{*}{\multicolumn{2}{|c|}{$\begin{array}{l}\text { Total } \\
\text { cohort } \\
O \quad E\end{array}$}} & \multirow[b]{3}{*}{$\operatorname{SMR}(95 \% C I)$} & \multicolumn{6}{|c|}{ First employed (calendar year) } \\
\hline & & & & \multicolumn{3}{|c|}{$\leqslant 1969$} & \multicolumn{3}{|c|}{$\geqslant 1970$} \\
\hline & & & & $O$ & $E$ & $\operatorname{SMR}(95 \% C I)$ & $O$ & $E$ & $\operatorname{SMR}(95 \% C I)$ \\
\hline $\begin{array}{l}\text { All causes: } \\
\text { Cardiovascular diseases }\end{array}$ & 85 & 59 & $1 \cdot 44(1 \cdot 16-1 \cdot 79)$ & 56 & 43 & $1 \cdot 32(1 \cdot 00-1 \cdot 72)$ & 29 & 16 & $1.78(1.21-2 \cdot 58)$ \\
\hline $\begin{array}{l}(390-458): \\
\text { Ischaemic heart diseases }\end{array}$ & 39 & 27 & $1.46(1.05-2.02)$ & 32 & 21 & $1.54(1.07-2.20)$ & 7 & 5.9 & $1.19(0.48-2 \cdot 46)$ \\
\hline $\begin{array}{l}(410-414) \\
\text { Cerebrovascular diseases }\end{array}$ & 34 & 20 & $1 \cdot 72(1 \cdot 20-2 \cdot 42)$ & 28 & 15 & $1 \cdot 81(1 \cdot 22-2 \cdot 65)$ & 6 & $4 \cdot 4$ & $1.38(0.51-3.00)$ \\
\hline $\begin{array}{l}(430-438) \\
\text { Respiratory diseases }\end{array}$ & 0 & $3 \cdot 0$ & $0(0 \cdot 00-1 \cdot 23)$ & 0 & $2 \cdot 4$ & $0(0.00-1.55)$ & 0 & 0.6 & $0(0.00-5 \cdot 95)$ \\
\hline $\begin{array}{l}(460-519) \\
\text { Accidents, poisoning, and } \\
\text { violence }(800-999)\end{array}$ & $\begin{array}{r}1 \\
17\end{array}$ & $\begin{array}{l}2 \cdot 9 \\
7 \cdot 8\end{array}$ & $\begin{array}{l}0.35(0.01-1.94) \\
2 \cdot 17(1.29-3.53)\end{array}$ & $\begin{array}{l}1 \\
4\end{array}$ & $\begin{array}{l}2 \cdot 2 \\
4 \cdot 0\end{array}$ & $\begin{array}{l}0.45(0.01-2.51) \\
1.01(0.27-2 \cdot 58)\end{array}$ & $\begin{array}{r}0 \\
13\end{array}$ & $\begin{array}{l}0.7 \\
3.9\end{array}$ & $\begin{array}{l}0(0 \cdot 00-5 \cdot 61) \\
3 \cdot 37(1 \cdot 79-5 \cdot 76)\end{array}$ \\
\hline $\begin{array}{l}\text { Malignant neoplasms } \\
(140-209)\end{array}$ & 26 & 16 & $1.65(1.09-2.44)$ & 19 & 12 & $1.62(1.00-2.57)$ & 7 & $4 \cdot 1$ & $1.72(0.69-3.55)$ \\
\hline
\end{tabular}


workers with the highest cumulative blood lead dose were very similar to those for the other workers (data not shown). Thus, the increased risk estimate for death from ischaemic heart diseases did not show a dose-response pattern with respect to lead and was also not related to latency period.

Forty malignant tumours were found in the total cohort during the observation period (SIR 1.27, 95\% CI 0.91-1.74; table 2). The non-significantly enhanced risk estimate of gastrointestinal cancer was based on only 11 incident malignancies (SIR $1 \cdot 84,95 \%$ CI $0 \cdot 92-3 \cdot 29$ ). A more detailed analysis with regard to specific positions was hampered by the limited numbers. No excesses of urinary, brain, or respiratory tract cancers were found.

With a minimum induction latency period of 10 and 15 years, respectively, the overall SIR was not increased, but was slightly so for gastrointestinal malignancies in the total cohort (SIR 2.14, 95\% CI 0.98-4.07; latency period of 15 years). All 11 cases of gastrointestinal tumours had occurred among those first employed up to 1969 , which raised the SIR to $2.44(95 \%$ CI $1.22-4.37)$ in this subcohort. With a latency period of 10 or 15 years the risk estimate was not affected (data not shown).

Restricting the analysis to the quartile of workers with the highest cumulative lead dose, the SIR for gastrointestinal cancer was increased (SIR 2.34; 95\% CI 1.07-4.45) compared with the total cohort. As was the case for the total cohort, the information available in the highest exposed quartile almost totally originates from the subcohort first employed up to 1969. Among those employed up to 1969, the SIRs were not affected by cumulative exposure to lead, or by applying latency periods of 10 or 15 years (table 3 ). Thus, the increased risk estimate for gastrointestinal malignancies was related to employment before 1970 and not to dose or latency time. The results were similar when exposure intensity over time or peak blood lead concentrations $>3.4 \mu \mathrm{mol} / 1$ were used instead of cumulative lead dose as the exposure variable.

\section{Discussion}

An increased total mortality, and more specifically an increased mortality from ischaemic heart diseases and all malignant neoplasms, was found among the workers exposed to lead. No dose-response pattern was found and the risk estimates did not increase when a latency period of 15 years was applied.

An increased incidence of gastrointestinal malignancies was found among the workers exposed to lead. This tendency was related to employment before 1970 and not to lead dose or to latency time.

\section{ASPECTS OF VALIDITY}

The size of this cohort is limited as was the observed number of deaths and incident malignancies. Thus, the statistical power to detect an increased mortality or morbidity for different site specific malignancies was rather low. On the other hand, the present study design allowed a fairly good individual lead dose estimate, based on blood samples drawn every two to three months since 1969. For some lead workers this index is based on about 170 blood lead samples. The lead exposure has been evaluated in terms of total blood lead dose during the time of employment at the smelter, as well as peak blood lead concentrations exceeding $3.4 \mu \mathrm{mol} / 1$, and exposure intensity over time. These comparisons gave similar results indicating a slightly increased cancer incidence in the gastrointestinal tract in workers exposed to lead. These risk estimates were not related to dose or latency time.

Most of the workers at the smelter had been exposed to inorganic lead for many years and there had been no concomitant exposure to other potentially carcinogenic metals such as arsenic, hexavalent chromium, nickel, and cadmium, which is common in primary smelters. ${ }^{13-17}$ There has been some exposure to antimony, which makes up about $3.5 \%$ (mean) of the produced lead ingots. No determinations of antimony in air have been performed at the smelter. Exposure to combustion gases that may contain organic

Table 2 Tumour morbidity (observed and expected) in the total cohort of workers exposed to lead in comparison with the county population, during the follow up period 1969-89. (The calculations were based on 664 subjects contributing 8703 person-years in the total cohort, 201 subjects with 3646 person-years in those first employed up to 1969, and 463 subjects with 5058 person-years in those first employed after 1969.)

\begin{tabular}{|c|c|c|c|c|c|c|c|c|c|}
\hline \multirow[b]{3}{*}{$I C D-7$} & \multirow{3}{*}{\multicolumn{2}{|c|}{$\begin{array}{l}\text { Total } \\
\text { cohort } \\
O \quad E\end{array}$}} & \multirow[b]{3}{*}{$\operatorname{SIR}(95 \% C I)$} & \multicolumn{6}{|c|}{ First employed (calendar-year) } \\
\hline & & & & \multicolumn{3}{|c|}{$\leqslant 1969$} & \multicolumn{3}{|c|}{$\geqslant 1970$} \\
\hline & & & & $O$ & $E$ & $\operatorname{SIR}(95 \% C I)$ & $O$ & $E$ & $\operatorname{SIR}(95 \% C I)$ \\
\hline \multicolumn{10}{|l|}{ Malignant neoplasms } \\
\hline$(140-209)$ & 40 & 32 & $1.27(0.91-1.74)$ & 31 & 22 & $1.38(0.95-1.98)$ & & $9 \cdot 1$ & $0.99(0.45-1.87)$ \\
\hline Gastrointestinal (150-154) & 11 & $6 \cdot 0$ & $1.84(0.92-3.29)$ & 11 & 4.5 & $2.44(1.22-4.37)$ & 0 & 1.5 & $0(0.00-2 \cdot 48)$ \\
\hline Oesophagus (150) & 2 & 0.5 & $4 \cdot 11(0.50-14 \cdot 8)$ & 2 & 0.4 & $5.45(0.66-19.7)$ & 0 & $0 \cdot 1$ & $0(0 \cdot 00-30 \cdot 7)$ \\
\hline Stomach (151) & 3 & $1 \cdot 6$ & $1.88(0.39-5.50)$ & 3 & $1 \cdot 3$ & $2.38(0.49-6.94)$ & 0 & $0 \cdot 3$ & $0(0 \cdot 00-11 \cdot 1)$ \\
\hline Small intestine (152) & 1 & 0.2 & $5.02(0.13-28.0)$ & 1 & $0 \cdot 1$ & $7.39(0.19-41.2)$ & 0 & $0 \cdot 1$ & $0(0.00-57.7)$ \\
\hline Colon (153) & 3 & $2 \cdot 1$ & $1.46(0.30-4.28)$ & 3 & 1.5 & $2.00(0.41-5.85)$ & 0 & 0.6 & $0(0.00-6.68)$ \\
\hline Rectum (154) & 2 & $1 \cdot 7$ & $1 \cdot 20(0 \cdot 15-4 \cdot 34)$ & 2 & $1 \cdot 2$ & $1.63(0.20-5.88)$ & 0 & $0 \cdot 4$ & $0(0.00-8 \cdot 49)$ \\
\hline Respiratory tract $(160-162)$ & 6 & $4 \cdot 5$ & $1.32(0.49-2 \cdot 88)$ & 4 & $3 \cdot \overline{3}$ & $1 \cdot 22(0.33-3 \cdot 13)$ & 2 & $1 \cdot 3$ & $1.59(0 \cdot 19-5 \cdot 73)$ \\
\hline Kidney (180) & 1 & $1 \cdot 2$ & $0.80(0 \cdot 02-4 \cdot 48)$ & 1 & 0.9 & $1 \cdot 12(0 \cdot 03-6 \cdot 26)$ & 0 & 0.4 & $0(0 \cdot 00-10 \cdot 4)$ \\
\hline \multicolumn{10}{|l|}{ Renal pelvis, ureter, bladder } \\
\hline$(181)$ & 3 & $2 \cdot 7$ & $1 \cdot 11(0 \cdot 23-3 \cdot 25)$ & 3 & $2 \cdot 0$ & $1 \cdot 51(0.31-4.42)$ & 0 & $0 \cdot 7$ & $0(0 \cdot 00-5 \cdot 15)$ \\
\hline $\begin{array}{l}\text { Brain, nervous system (193) } \\
\text { Lymphoma, myeloma }\end{array}$ & 1 & $1 \cdot 3$ & $0.75(0.02-4 \cdot 20)$ & 0 & $0 \cdot 8$ & $0(0 \cdot 00-4 \cdot 70)$ & 1 & $0 \cdot 5$ & $1 \cdot 8(0 \cdot 05-10 \cdot 3)$ \\
\hline \multirow{2}{*}{$\begin{array}{l}\text { Lymphoma, myeloma } \\
(200-203) \\
\text { Leukaemia }(204-207)\end{array}$} & 2 & $1 \cdot 8$ & $1.09(0.13-3.94)$ & 2 & $1 \cdot 2$ & $1.71(0.2$ & 0 & 0.7 & $0<0$ \\
\hline & 1 & 0.9 & $1.18(0.03-6.55)$ & 1 & 0.6 & $1.75(0.04-9.77)$ & 0 & 0.3 & $0(0 \cdot 00-12 \cdot 3)$ \\
\hline
\end{tabular}


Table 3 Tumour morbidity (observed and expected) in the quartile with the highest cumulative blood lead dose among workers exposed to lead first employed up to 1969 (128 subjects, 1958 person-years) in comparison with the county population, during the follow up period 1969-89. (Calculations based on 110 subjects with 1437 person-years for a latency period of 10 years, 94 subjects with 1095 person-years for a latency period of 15 years.)

\begin{tabular}{|c|c|c|c|c|c|c|c|c|c|}
\hline \multirow[b]{2}{*}{$I C D-7$} & \multicolumn{3}{|c|}{ No latency period } & \multicolumn{3}{|c|}{$\begin{array}{l}\text { Latency period of at least } \\
10 \text { years }\end{array}$} & \multicolumn{3}{|c|}{$\begin{array}{l}\text { Latency period of at least } \\
15 \text { years }\end{array}$} \\
\hline & $O$ & $E$ & $\operatorname{SIR}(95 \% C I)$ & $O$ & $E$ & $\operatorname{SIR}(95 \% C I)$ & $O$ & $E$ & $\operatorname{SIR}(95 \% C I)$ \\
\hline $\begin{array}{l}\text { Malignant neoplasms } \\
\quad(140-209) \\
\text { Gastrointestinal }\end{array}$ & 23 & 18 & $1 \cdot 28(0.82-1 \cdot 94)$ & 20 & 16 & $1 \cdot 28(0 \cdot 79-2 \cdot 00)$ & 20 & 13 & $1.51(0.94-2.37)$ \\
\hline $\begin{array}{l}(150-154) \\
\text { Oesophagus (150) } \\
\text { Stomach }(151) \\
\text { Small intestine (152) } \\
\text { Colon }(153) \\
\text { Rectum (154) }\end{array}$ & $\begin{array}{l}9 \\
1 \\
3 \\
1 \\
3 \\
1\end{array}$ & $\begin{array}{l}3 \cdot 7 \\
0 \cdot 3 \\
1 \cdot 1 \\
0 \cdot 1 \\
1 \cdot 2 \\
1 \cdot 0\end{array}$ & $\begin{array}{l}2.43(1.11-4.62) \\
3.28(0.08-18 \cdot 3) \\
2.83(0.58-8 \cdot 28) \\
9.45(0.24-52 \cdot 7) \\
2.46(0.51-7 \cdot 18) \\
0.99(0.03-5 \cdot 53)\end{array}$ & $\begin{array}{l}7 \\
1 \\
2 \\
1 \\
2 \\
1\end{array}$ & $\begin{array}{l}3 \cdot 2 \\
0 \cdot 3 \\
0 \cdot 9 \\
0 \cdot 1 \\
1 \cdot 1 \\
0 \cdot 9\end{array}$ & $\begin{array}{l}2 \cdot 18(0 \cdot 88-4 \cdot 49) \\
3 \cdot 73(0 \cdot 09-20 \cdot 8) \\
2 \cdot 20(0 \cdot 27-7 \cdot 94) \\
11.0(0.28-61 \cdot 5) \\
1.88(0 \cdot 23-6 \cdot 80) \\
1 \cdot 14(0.03-6 \cdot 33)\end{array}$ & $\begin{array}{l}7 \\
1 \\
2 \\
1 \\
2 \\
1\end{array}$ & $\begin{array}{l}2 \cdot 7 \\
0 \cdot 2 \\
0 \cdot 8 \\
0 \cdot 1 \\
0 \cdot 9 \\
0 \cdot 7\end{array}$ & $\begin{array}{c}2.57(1.03-5 \cdot 30) \\
4.42(0.11-24 \cdot 6) \\
2.60(0.32-9 \cdot 40) \\
13.0(0.33-72 \cdot 5) \\
2.22(0.27-8 \cdot 02) \\
1.34(0.03-7 \cdot 48)\end{array}$ \\
\hline $\begin{array}{l}\text { Respiratory tract } \\
(160-162) \\
\text { Kidney }(180) \\
\text { Renal pelvis, ureter, }\end{array}$ & $\begin{array}{l}2 \\
1\end{array}$ & $\begin{array}{l}2 \cdot 6 \\
0 \cdot 7\end{array}$ & $\begin{array}{l}0.76(0.09-2 \cdot 75) \\
1.43(0.04-7 \cdot 97)\end{array}$ & $\begin{array}{l}2 \\
1\end{array}$ & $\begin{array}{l}2 \cdot 3 \\
0 \cdot 6\end{array}$ & $\begin{array}{l}0 \cdot 88(0 \cdot 11-3 \cdot 17) \\
1 \cdot 70(0 \cdot 04-9 \cdot 49)\end{array}$ & $\begin{array}{l}2 \\
1\end{array}$ & $\begin{array}{l}1.9 \\
0.5\end{array}$ & $\begin{array}{l}1.04(0.13-3 \cdot 76) \\
2 \cdot 06(0.05-11.5)\end{array}$ \\
\hline $\begin{array}{l}\text { bladder (181) } \\
\text { Brain, nervous system }\end{array}$ & 2 & $1 \cdot 6$ & $1 \cdot 24(0 \cdot 15-4 \cdot 48)$ & 2 & $1 \cdot 4$ & $1 \cdot 42(0 \cdot 17-5 \cdot 13)$ & 2 & $1 \cdot 2$ & $1.69(0 \cdot 20-6 \cdot 10)$ \\
\hline $\begin{array}{l}\text { (193) } \\
\text { Lymphoma, myeloma }\end{array}$ & 0 & 0.5 & $0(0 \cdot 00-6 \cdot 84)$ & 0 & 0.4 & $0(0 \cdot 00-8 \cdot 68)$ & 0 & 0.3 & $0(0.00-10.9)$ \\
\hline $\begin{array}{l}(200-203) \\
\text { Leukaemia (204-207) }\end{array}$ & $\begin{array}{l}1 \\
0\end{array}$ & $\begin{array}{l}0.9 \\
0.4\end{array}$ & $\begin{array}{l}1 \cdot 16(0 \cdot 03-6 \cdot 45) \\
0(0 \cdot 00-8 \cdot 58)\end{array}$ & $\begin{array}{l}1 \\
0\end{array}$ & $\begin{array}{l}0 \cdot 7 \\
0.4\end{array}$ & $\begin{array}{l}1.37(0.03-7.62) \\
0(0.00-9 \cdot 97)\end{array}$ & $\begin{array}{l}1 \\
0\end{array}$ & $\begin{array}{l}0.6 \\
0.3\end{array}$ & $\begin{array}{l}1 \cdot 65(0 \cdot 04-9 \cdot 17) \\
0(0 \cdot 00-11 \cdot 9)\end{array}$ \\
\hline
\end{tabular}

carcinogens (PAHs) has been limited, as has exposure to irritating gases such as sulphur dioxide.

In Sweden, more reliable information on tumours is gained from incidence data from the Swedish Cancer Registry, in comparison with the Cause of Death Registry. ${ }^{18}$ Thus, the morbidity figures in tables 2 and 3 would have a higher validity than cancer mortality data presented in this study.

For workers employed at the smelter before 1969 , their previous lead exposure has been estimated on their exposure during 1969. As the airborne exposure at the smelter has decreased over the years in parallel with improvement of exhaust ventilation, repeated reconstruction and modernisation of the processes, as well as increased use of breathing protective devices (figure), the accumulated lead exposure for these workers has probably been somewhat underestimated.

\section{GASTROINTESTINAL MALIGNANCIES}

In a recent meta-analysis of case control and cohort studies of people exposed to lead, the combined results from 10 studies showed a significant excess risk of stomach cancer, relative risk $(R R)=1.33(95 \% \mathrm{CI} 1 \cdot 18-1 \cdot 49) .{ }^{19} \mathrm{It}$ should, however, be emphasised that this risk estimate has not been adjusted for potential confounders for stomach cancer such as cigarette smoking, high salt intake, reduced intake of fresh fruits and vegetables, consumption of smoked or salted meat and fish, and infection with Helicobacter pylori. It is, thus, still not clarified whether occupational lead exposure may cause stomach cancer. The limited size of the present study hampered a further evaluation of site specific gastrointestinal malignancies.

OTHER MALIGNANCIES

The SMRs and SIRs for respiratory tract malignancies were not increased in our study. This is in accordance with several previous epidemiological studies of lead workers that did not find an increased mortality or morbid- ity in respiratory malignancies or malignancies in general. ${ }^{140-25}$ Combined results from a recent meta-analysis of case-control and cohort studies $^{19}$ showed a significant excess risk of lung cancer ( $R R \quad 1 \cdot 29 ; 95 \%$ CI $1 \cdot 10-1 \cdot 50)$ as well as bladder cancer ( $R R$ $1 \cdot 41 ; 95 \%$ CI $1 \cdot 16-1 \cdot 71)$. In our study, we found no risk excesses for malignancies in the urinary tract or brain. Similar negative findings regarding brain tumours have been reported by Cooper et al. ${ }^{13}$ On the other hand, an increased risk of gliomas was associated with lead exposure in a recent Finnish case-control study. ${ }^{26}$

\section{CARDIOVASCULAR DISEASES}

An increased mortality from cardiovascular diseases has been found in several epidemiological studies of lead workers. These enhanced risks refer mainly to cerebrovascular diseases. ${ }^{20212327}$ Furthermore, excessive deaths from hypertensive diseases have been found in battery plant and lead production workers. ${ }^{13}$ Other studies have been negative. ${ }^{1415}$ The interpretation of these studies is hampered by lack of data on smoking.

It has been indicated that there is an increase of systolic and diastolic blood pressure by 1-2 $\mathrm{mm} \mathrm{Hg}$ for each doubling of blood lead, in the blood lead range in the general population. ${ }^{28}$ Several mechanisms for this have been discussed-for example, a direct lead action on vascular smooth muscle, as well as renal effects mediated through the renin-angiotensin system. ${ }^{29}$ Lead may also alter renal vascular reactivity to $a$-adrenergic agents. ${ }^{30}$ Also, direct cardiovascular effects may occur. ${ }^{29}$ Thus, a lead effect on blood pressure may contribute to the increased mortality from cerebrovascular deaths reported in some studies, ${ }^{20212327}$ and possibly also to other cardiovascular deaths. ${ }^{29}{ }^{31}$ In accordance with this theory, the mortality from ischaemic heart diseases was raised in the present cohort. The SMR did not increase with increasing lead dose or when a 
latency period of 10 or 15 years was applied. The interpretation is complicated by lack of data on smoking.

\section{Conclusion}

A slightly increased incidence of gastrointestinal malignancies in lead workers employed before 1970, as well as an increased mortality from ischaemic heart diseases, was indicated in this study. The risk estimates did not show a dose-response pattern and were not associated with latency time. The results must also be interpreted with caution because of limited numbers, and lack of information on dietary and smoking habits. Most epidemiological studies about the relation between exposure to inorganic lead and the development of malignancies have been negative. Small excess risks in some studies could be explained by confounding factors and are often difficult to evaluate because of lack of individual exposure data on cumulative lead exposure. The animal experimental findings and the increased risks indicated in some studies, especially for stomach, lung, and bladder cancer in a recent meta-analysis ${ }^{19}$ still keeps the question of human carcinogenicity on the agenda.

This work was supported by grants from the Swedish Work Environment Fund, the Swedish Cancer Society, and the Medical Faculty, Lund University.

1 Zollinger HU. Durch chronische Bleivergiftung erzeugte Nierenadenome und-carcinome bei Ratten und ihre Nierenadenome und-carcinome bei Ratten und ihre Beziehungen zu den entsprechenden Neubild

2 Tanner DC, Lipsky MM. Effect of lead acetate on N-(4'-fluoro-4-biphenyl)acetamide-induced renal carcinogenesis in the rat. Carcinogenesis 1984;5:1109-13.

3 Kasprzak KS, Hoover KL, Poirier LA. Effects of dietary calcium acetate on lead subacetate carcinogenicity in kidneys of male Sprague-Dawley rats. Carcinogenesis 1985;6: 279-82.

4 Koller LD, Kerkvliet NI, Exon JH. Neoplasia induced in male rats fed lead acetate, ethyl urea, and sodium nitrite. Toxicol Pathol 1985;13:50-7.

5 IARC. IARC monographs on the evaluation of carcinogenic risks to humans. Overall evaluations of carcinogenicity: an risks to humans. Overall evaluations of carcinogenicity: an updating of LARC monographs volumes 1 to 42 . Lyon: International Age

6 Nogueira E. Rat renal carcinogenesis after chronic simultaneous exposure to lead acetate and $\mathrm{N}$-nitrosodiethylamine. Virchows Arch B 1987;53:365-74.

7 Magos L. Epidemiological and experimental aspects of metal carcinogenesis: physicochemical properties, kinet- ics and the active species. Environ Health Perspect 1991;95:157-89.

8 Baker EL, Goyer RA, Fowler BA, Khettry U, Bernard DB, Adler $S$, et al. Occupational lead exposure, nephropathy, and renal cancer. Am $₹$ Ind Med 1980;1:139-48.

9 Lilis R. Long-term occupational lead exposure, chronic nephropathy, and renal cancer: a case report. $A m \mathcal{F}$ Ind Med 1981;2:293-7.

10 Partanen T, Heikkila P, Hernberg S, Kauppinen T, Moneta G, Ojajarvi A. Renal cell cancer and occupational exposure to chemical agents. Scand 7 Work Environ Health 1991;17:231-9.

11 Hogstedt C, Hane M, Agrell A, Bodin L. Neuropsychological test results and symptoms among workers psychological test results and symptoms among workers Med 1983;40:99-105.

12 Schütz A. Metabolism of inorganic lead at occupational exposure. Lund, Sweden: Departments of Occupational Medicine and Environmental Hygiene, Lund University, 1986. (Doctoral dissertation.)

13 Cooper WC, Wong O, Kheifets L. Mortality among employees of lead battery plants and lead-producing plants, 1947-80. Scand $₹$ Work Environ Health 1985 11:331-45.

14 Selevan SG, Landrigan PJ, Stern FB, Jones JH. Mortality of lead smelter workers. Am $\mathcal{F}$ Epidemiol 1985;122:673-83.

15 Gerhardsson L, Lundström N-G, Nordberg G, Wall S Mortality and lead exposure: a retrospective cohort study Mortality and lead exposure: a retrospective cohort study
of Swedish smelter workers. Br $\mathcal{F}$ Ind Med 1986;43: of Swedish

16 Gerhardsson L, Brune D, Nordberg GF, Wester PO. Multielemental assay of tissues of deceased smelter workers and controls. Sci Total Environ 1988;74:97-110.

17 Ades AE, Kazantzis G. Lung cancer in a non-ferrous smelter: the role of cadmium. $\mathrm{Br} F$ Ind Med 1988;45: 435-42.

18 Mattson B, Wallgren A. Completeness of the Swedish cancer register. Non-notified cancer cases recorded on death certificates in 1978. Acta Radiol Oncol 1984;23:305-13.

$19 \mathrm{Fu} \mathrm{H}$, Boffetta P. Cancer and occupational exposure to inorganic lead compounds:a meta-analysis of published inorganic lead compounds:a meta-analys
data. Occup Environ Med 1995;52:73-81.

20 Dingwall-Fordyce I, Lane RE. A follow-up study of lead workers. Br ₹ Ind Med 1963;20:313-5.

21 McMichael AJ, Johnson HM. Long-term mortality profile of heavily-exposed lead smelter workers. $f$ Occup Med 1982;24:375-8.

22 Sweeney MH, Beaumont J, Waxweiler RJ, Halperin WE An investigation of mortality from cancer and other causes of death among workers employed at an east
Texas chemical plant. Arch Environ Health 1986;41:23-8.

23 Malcolm D, Barnett HAR. A mortality study of lead workers 1925-76. Br f Ind Med 1982;39:404-10.

24 Fanning D. A mortality study of lead workers, 1926-85. Arch Environ Health 1988;43:247-51.

25 Wicklund KG, Daling JR, Allard J, Weiss NS. Respiratory cancer among orchardists in Washington state, 1968 to 1980. F Occup Med 1988;30:561-4.

26 Anttila A. Occupational exposure to lead and risk of cancer. Academic dissertation, Department of Public Health University of Tampere, Finland, 1994: 1-86.

27 Davies JM. Long term mortality study of chromate pigmen workers who suffered lead poisoning. Br 7 Ind Med 1984 41:170-8.

28 Pocock SJ, Shaper AG, Ashby D, Delves HT, Clayton BE. The relationship between blood lead, blood pressure, The relationship between blood lead, blood pressure, stroke, and heart attacks in middle-a
Environ Health Perspect 1988;78:23-30.

29 Schwartz J. Lead, blood pressure, and cardiovascular disease in men and women. Environ Health Perspect 1991;91: 71-5.

30 Goyer RA. Mechanisms of lead and cadmium nephrotoxicity. Toxicol Lett 1989;46:153-62.

31 Møller L, Kristensen TS. Blood lead as a cardiovascular risk factor. Am ₹ Epidemiol 1992;136:1091-100.

\section{Rejected manuscripts}

From February 1994, authors whose submitted articles are rejected will be advised of the decision and one copy of the article, together with any reviewers' comments, will be returned to them. The fournal will destroy remaining copies of the article but correspondence and reviewers' comments will be kept. 